\title{
Ultrasensitive signal detection by a guanylyl cyclase chemoreceptor
}

\author{
U Benjamin Kaupp \\ From 7th International Conference on cGMP Generators, Effectors and Therapeutic Implications \\ Trier, Germany. 19-21 June 2015
}

\section{Background}

Sperm navigate to the egg in a gradient of a chemoattractant for fertilization - a mechanism called chemotaxis. In sea urchin, the chemoattractant peptide binds to a chemoreceptor guanylyl cyclase (GC) on the sperm surface. Activation of the GC initiates a sequence of signaling events that eventually results in $\mathrm{Ca} 2+$ influx and a change in swimming direction. We studied the GC properties that allow sperm to track the chemoattractant with singlemolecule precision on a millisecond time scale. A high density (9.103 GC molecules/ $\mu \mathrm{m} 2)$ and a subnanomolar ligand affinity provide a high ligand-capture efficacy. The sperm surface represents an almost perfect absorber. The peptide-induced GC activity is terminated by multiple dephosphorylation steps, which provide a means of precise lifetime control and, thereby, reduces "molecular noise". Several experiments suggest that GC undergoes autodephosphorylation. Future experiments need to clarify, whether the GC entertains phosphatase and kinase activity, possibly in the kinase-homology domain (KHD).

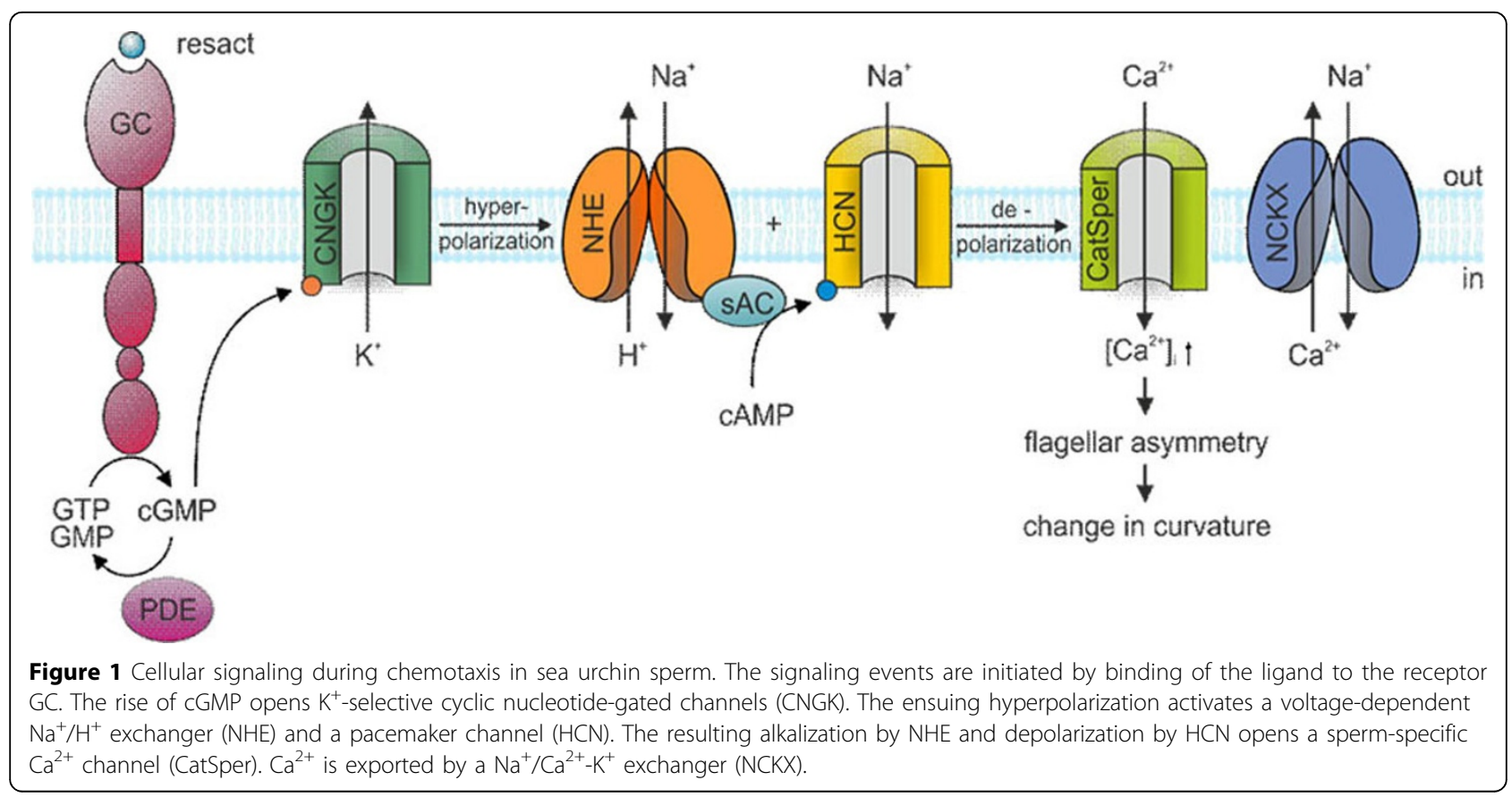

Correspondence: u.b.kaupp@caesar.de

Department of Molecular Sensory Systems, Center of Advanced European

Studies and Research (caesar), Bonn, Germany 
The turnover of cGMP synthesis of 72 cGMP molecules/ sec or about 11 cGMP molecules/GC*/lifetime is sufficient to open a few cGMP-gated channels and to produce a unitary voltage response of about $2 \mathrm{mV}$. The receptor GC can bind the ligand over six orders of magnitude of concentrations. The shallow binding curve might reflect negative cooperativity among binding sites; alternatively receptor population might be composed of a mixture of receptors with a range of $K_{1 / 2}$ values.

Published: 2 September 2015

doi:10.1186/2050-6511-16-S1-A20

Cite this article as: Kaupp: Ultrasensitive signal detection by a guanylyl cyclase chemoreceptor. BMC Pharmacology and Toxicology 2015 16(Suppl 1):A20.
Submit your next manuscript to BioMed Central and take full advantage of:

- Convenient online submission

- Thorough peer review

- No space constraints or color figure charges

- Immediate publication on acceptance

- Inclusion in PubMed, CAS, Scopus and Google Scholar

- Research which is freely available for redistribution

Submit your manuscript at www.biomedcentral.com/submit
C Biomed Central 